УДК 94:378(477.42)

DOI: https://doi.org/10.26642/ten-2019-2(84)-3-9

\author{
В.В. Свдокимов, д.е.н., проф. \\ О.В. Олійник, д.е.н., проф. \\ А.О. Чагайда, к.т.н., доц. \\ Державний університет «Житомирська політехніка»
}

\title{
Становлення Волинського (Житомирського) індустріального технікуму як сдиного вищого технічного навчального закладу Волинської губернії
}

Сто років назад було розпочато роботу і у 1920 році створено перший вищий заклад інженернотехнічної освіти Волинської губернії. У складних умовах ліквідації наслідків громадянської війни та відновлення промисловості, за відсутності фінансування, а інколи і харчування, ентузіасти справи прикладали титанічні зусилля для відновлення навчального процесу в існуючих та започаткування нових навчальних закладів з більш високим рівнем освіти. Результати цієї діяльності відображено у працях безпосередніх учасників подій - Г. Гринька, Я. Ряппо, Я. Звігальського, а також у грунтовних дослідницьких роботах С. Сірополко, С. Майбороди, В. Липинського, А. Вороха, М. Мірошниченка, I. Лікарчука, М. Харламова.

Метою дослідження $є$ аналіз організації і розвитку Волинського індустріального технікуму та висвітлення діяльності губернського відділу професійної освіти у цьому напрямі.

У першій половині 20-х років XX століття в Україні було визнано необхідність районування спеціалізацій вищої технічної освіти, відповідно до потреб промисловості в інженерах та наявності виробничої бази для навчальних закладів, для чого намічено утворення двох типів шкіл: на кожному заводі мала бути організована професійно-технічна школа для підготовки висококваліфікованих працівників, а другим типом мав стати кущовий технікум для обслуговування групи із кількох заводів для підготовки кадрів середньо-технічного персоналу [1].

У березні 1920 року група викладачів Житомирського землемірного училища відкрила Волинський земельний політехнікум у складі трьох відділень: електротехнічного, сільськогосподарських технологій та гідротехнічного, навчання у якому відбувалося лише з теоретичних дисциплін (вища математика, теоретична механіка тощо), без будь-якої практичної підготовки. Теоретичне викладання було на достатньо хорошому рівні, тому що в зимовий період 1919-1920 років в Житомирі ще були високопрофесійні викладачі - проф. Сокольцов, інженери Грязнов, Кандалінцев та інші [2]. У грудні цього ж року Земельний політехнікум було вилучено із підпорядкування Губземвідділу, переведено до Губпрофосу та реорганізовано у технікум 3 трьома відділеннями: сільськогосподарського машинобудування, інженерно-будівельним та хімічних технологій, а також річного підготовчого відділення (нульового курсу) [3].

1920-1921 навчальний рік у житті Волинського індустріального технікуму (ВІТ) можна назвати періодом благодійності. Оскільки на цей час припадає бурхливий розвиток вищої технічної школи в Україні, то з усією гостротою постала проблема підготовки до викладацької діяльності випускників радянської вищої школи. На початкових етапах становлення вищої технічної школи важливою проблемою було забезпечення іiі науково-педагогічними кадрами, а у 1920-х роках ця проблема гостро стояла в усіх освітніх закладах України, адже велика кількість української інтелігенції залишила країну в роки революції і опинилася за кордоном [4]. Органи Волинської губернської професійної освіти до весни 1921 року ще не запрацювали, тому ВІТ розпочинав свою діяльність без достатньої кількості викладачів та фінансових засобів для існування. Ряд колишніх викладачів земельного політехнікуму - Шпігель Софія Абрамівна, Пікман Борис Мойсейович, Ріненберг Роберт Олексійович, Платонов Анатолій Сергійович та інші читали лекції в індустріальному технікумі через співчуття до молоді, тому що винагорода за роботу була мізерною, а продовольчі пайки не відпускались. Весною, з початком городньої кампанії, голодуючі викладачі з головою поринали в обробку земельних ділянок, де їх і знаходили посланці від студентства. Влітку 1921 року діячі Губпрофосу, після запеклої полеміки щодо подальшої долі технікуму, спробували закритти навчальний заклад 3 вересня цього ж року. Це рішення було проігноровано студентами та викладачами, які продовжили навчальний процес, тому губернська профрада була змушена змінити своє рішення і делегувати свого представника на завідування технікумом [2]. У результаті керуючим технікумом 313 вересня 1921 року став інженер Суботін Михайло Петрович, а колишній завідувач (з листопада 1920 до вересня 1921 року) Чеховський Йосип Іванович став його заступником та керуючим навчальною частиною [5]. Незважаючи на скептицизм частини студентів і викладачів, відсутність списочного складу (колишній секретар технікуму виїхав за кордон) та погані побутові умови, 24 вересня розпочалась організаційна робота, 11 жовтня було проведено вступні випробування і з 25 жовтня 1921 року розпочались аудиторні заняття. Для нормалізації роботи ВІТу губернський комітет постачання гарантував викладацькому персоналу незначну кількість академпайків, Рада Народного Господарства 
передала черепично-бетонний завод, а губернський виконком виділив 1700000 карбованців на ремонт хімічної лабораторії [2].

Приймальні випробування до технікуму у 1921 році з’ясували кричущу неготовність молоді 3 математики, безграмотність та вкрай низький загальний розвиток. Це явище постійно зростало з кожним роком і випускники трудових шкіл 1919 року знали більше, ніж ті, які закінчили у 1920 році. Після повторного приймального випробування із 97 осіб до ВІТу було зараховано лише 19 [2]. Для покращення рівня підготовки вступників, відповідно до трьох відділень технікуму, було організовано три Житомирські професійно-технічні школи: першу професійно-технічну школу залишили механічною, другу реорганізовано у будівельну ім. Артема, а третю професійну школу хімічної спеціальності знову організували на початку 1922 року. За даними Волинського губпрофосу статистичні дані по викладачах і учнях індустріальної вертикалі, станом на травень 1923 року, представлено в таблиці 1 [6].

Таблиця 1

Статистичні дані по викладачах і учнях індустріальної вертикалі

\begin{tabular}{|c|c|c|c|c|}
\hline $\begin{array}{c}\text { № } \\
\text { 3/п }\end{array}$ & Назва закладу & $\begin{array}{c}\text { Кількість } \\
\text { викладачів } \\
\text { і адміністративно- } \\
\text { господарського } \\
\text { персоналу }\end{array}$ & Кількість учнів & $\begin{array}{c}\text { Співвідношення } \\
\text { кількості } \\
\text { співробітників } \\
\text { закладу освіти до } \\
\text { кількості учнів, \% }\end{array}$ \\
\hline 1 & $\begin{array}{c}\text { Волинський індустріальний } \\
\text { технікум }\end{array}$ & 73 & 174 & 25 \\
\hline 2 & $\begin{array}{c}\text { Перша Житомирська } \\
\text { профшкола }\end{array}$ & 17 & 106 & 32 \\
\hline 3 & $\begin{array}{c}\text { Друга Житомирська } \\
\text { профшкола ім. Артема }\end{array}$ & 29 & 90 & 16 \\
\hline 4 & Хімічна профшкола & 12 & 85 & 32 \\
\hline
\end{tabular}

У той час «пролетаризація» вищих шкіл, в розумінні комплектування їх робітничо-селянським елементом, здійснювалася шляхом своєрідного порядку прийому, який полягав у тому, що до вищих шкіл приймалися насамперед ті, які закінчили робітничі факультети, - вони вступали без іспиту, а всі інші мали скласти іспит, причому іспит проводився за куріальною системою (були курія робітників, селян, службовців тощо). Заздалегідь визначалися норми прийому робітників, селян та інших. Як свідчив Нарком освіти УСРР у 1927-1933 роках М. Скрипник, «3 робітників приймаємо всіх, хто склав іспит, хоча б не робітники мали й вищий рівень знань». Що ж до робітників і селян, які не були робфаківцями (не закінчували робітничі факультети) і не закінчили підготовчі курси при вищих школах, тобто не зараховувались автоматично, то їм доводилося складати іспит у відповідній курії, для яких програми мали значно нижчий рівень, порівняно з іншими куріями, щоб забезпечити вищу школу робітничо-селянськими силами [7].

Той самий М. Скрипник не раз давав належну оцінку цій системі прийому: «Зниження умов прийому це велика помилка, і тепер, підраховуючи наслідки прийому, треба нам зробити відповідні висновки, бо зниження умов прийому для робітників і селян під час прийняття до вишів не забезпечує робітничий клас своєю пролетарською справжньою інтелігенцією. Намагання пролізти, як-небудь обійти, знайти засоби, щоб прикрити своє незнання, норма на прийняття з одним-двома незадовільними предметами - це шлях до розбещення пролетарської молоді, до класового переродження, до поширення дрібнобуржуазного впливу на нашу робітничо-селянську молодь. Під час навчання у виші дрібна буржуазія вживає усіх заходів, щоб якнайкраще встигати, і вони з другого та третього курсу займають місця на семінарах, а потім ідуть в аспіранти, тому що вони краще підготовлені, аніж робітники і селяни. От що значить приймати робітників і селян до вишу з недостатнім знанням - це ніщо інше, як готувати самим собі прірву» [7].

Зрозуміло, що кожен з тих кандидатів, що бажає вступити до вищої школи, намагався потрапити до курії робітників чи селян, а для цього треба мати посвідку на доказ робітничо-селянського походження або потрапити в число тих кандидатів, яких командирують до вищої школи партійні й професійні організації. Як засвідчує М. Скрипник, «багато організацій надають рекомендації і оцінку деяким вступникам до вишу, дають і посвідчення, і документи, що такий-то є робітник, з таким-то стажем, що він бідняк чи середняк, $\mathrm{i}$ його приймають до вишу як робітника чи бідняка-селянина, а потім виявляється, що оцей зарекомендований робітничими і організаціями Комітету Незаможних Селян і сільрадами є чужий нам елемент - куркуль, непман, контрреволюціонер. Наша лінія полягає в тому, - і ми дали відповідні директиви, - щоб усіх тих, що при вступові до вишу притаїли своє соціальне походження чи положення, без жалю звільняти 3 вишу». Щоб викрити такі «злочини» 3 підробленням відомостей про соціальний стан, час від часу проводились у вищих школах так звані «чистки», або як м'яко висловлювався Я. Ряппо, «перереєстрація», внаслідок якої 
без жалю викидали з вищої школи студентів, навіть тих, що виказали добрі успіхи, лише через те, що притаїли своє соціальне походження [7].

Згідно із реформою системи освіти було встановлено два типи вищої школи, а саме: технікуми, що готували спеціалістів вузького профілю, та інститути, які випускали інженерів та інших спеціалістів широкого профілю. У 1921 році на території УСРР функціонувало 42 інститути і 145 технікумів [8]. Відповідно до рішень по реформуванню системи освіти затверджувалися спеціальності для кожного типу навчальних закладів. Спеціальності Волинського індустріального технікуму були визначені на особливих факультетських засіданнях у грудні 1921 року за участі делегатів профспілок і господарчих органів губернії [3]. У травні 1922 року відділ професійно-технічної освіти Волинської губернської ради народного господарства у своєму висновку зауважує, що спеціальності Волинського індустріального технікуму обрано правильно i повністю відповідають місцевим культурно-виробничим потребам. Так, на механічному напрямі здійснювали підготовку за двома вузькими спеціалізаціями - сільськогосподарське машинобудування (малась на увазі підготовка інженерів для кооперативних підприємств по ремонту сільськогосподарських машин, типу Житомирського заводу «Сільмаш») і лісопильна справа (підготовка технічних керівників для 30 діючих лісопильних заводів Житомирського, Овруцького та інших повітів). Спеціальності будівельної направленості були розраховані на підготовку інженерів-будівельників, керівників дорожньо-мостового та сільського будівництва. Наявність у розпорядженні технікуму навчально-практичного бетонно-черепичного заводу із лабораторією по технічному і механічному випробуванню продукції, зумовило подальший розвиток в губернії будівництва вогнестійких споруд із відповідних матеріалів. Будівельне каміння та природній бетон, аналіз яких було розпочато у 1914 році і перервано на 7 років через війну та революцією, знову стали предметом глибокого наукового дослідження і можливого вивчення на ще одній рекомендованій спеціальності - технології будівельних матеріалів. I до останнього, третього напряму - хімічного, в першу чергу належала підготовка інженерів та керівників фарфорово-фаянсової промисловості, яка на той час вже мала 150 -ти річну історію виробництва. Окрім технології неорганічних речовин (фарфорове, фаянсове, керамічне і склоплавильне виробництво), на хімічному напрямі також відбувалася підготовка 3 технології органічних речовин (шкіряна справа, винокуріння, миловаріння) [9].

За результатами аналізу роботи технікуму у травні 1922 року Волгубпрофосу звернувся з клопотанням зареєструвати існуючий у м. Житомир технікум у загальноукраїнській профшкільній мережі під назвою «Волинський індустріальний політехнікум 3 правами ВНЗ» або іншою рівнозначною назвою [3] (дані наведено в таблиці 2).

Таблицяя 2

Кількість студентів по факультетах Волинського індустріального університету

\begin{tabular}{|c|c|c|c|c|c|}
\hline \multirow{2}{*}{ Дата } & \multicolumn{5}{|c|}{ Кількість студентів } \\
\cline { 2 - 6 } & механічний & будівельний & хімічний & підготовчий & разом \\
\hline $\begin{array}{c}\text { Листопад } \\
\text { 1921 року }\end{array}$ & $\mathbf{9 9}$ & $\mathbf{2 0}$ & $\mathbf{4 4}$ & $\mathbf{6 2}$ & $\mathbf{2 3 1}$ \\
\hline $\begin{array}{c}\text { Травень } \\
1922 \text { року }\end{array}$ & $\mathbf{7 3}$ & $\mathbf{2 1}$ & $\mathbf{2 7}$ & $\mathbf{5 9}$ & $\mathbf{1 8 0}$ \\
\hline $\begin{array}{c}\text { Прийнято } \\
\text { на 1-й курс у } \\
\text { жовтні 1922 року }\end{array}$ & $\mathbf{3 2}$ & $\mathbf{2 1}$ & $\mathbf{3 0}$ & - & $\mathbf{8 3}$ \\
\hline
\end{tabular}

У травні 1923 року навчання на підготовчих курсах проходив 61 учень, а другий рік існування курсів підтвердив їх життєздатність та значну користь для ВІТу: забезпечення вступу не менше 50 підготовлених учнів на 1 курс технікуму [10].

Для вирішення питання розміщення аудиторій і лабораторій 4 вересня 1922 року ВІТу, після тривалих перемовин, офіційно передано будівлю колишньої 2-ї гімназії м. Житомира (лише 21 вересня приміщення фактично звільнено представниками школи червоних командирів 44-ї дивізії). У зв'язку з тим, що будівля не ремонтувалася з 1914 року, на першочерговий ремонт виділено 50000 крб, а також створено вже в новому приміщенні, на хімічному факультеті окремі лабораторії кількісного аналізу та якісного аналізу (за рахунок хімічної лабораторії, що згідно з рішенням Губпрофосу передано технікуму). Практичні роботи студентів механічного факультету проводилися під керівництвом завідувача Ф.Я. Кашкадаєва у механічних майстернях, що раніше належали I профтехнічній школі та передані технікуму постановою профосу (фактична передача була передбачена з 1.01.1924 року) [11].

Бібліотеку технікуму засновано у лютому 1922 року і їі початковий книжковий фонд складав 160 томів і на 1.01.1923 року збільшився до 791 тому [12]. Відкриття читальної зали бібліотеки відбулося 29 жовтня 1922 року [13]. Розподіл книг за відділами бібліотеки відображено на рисунку 1. 


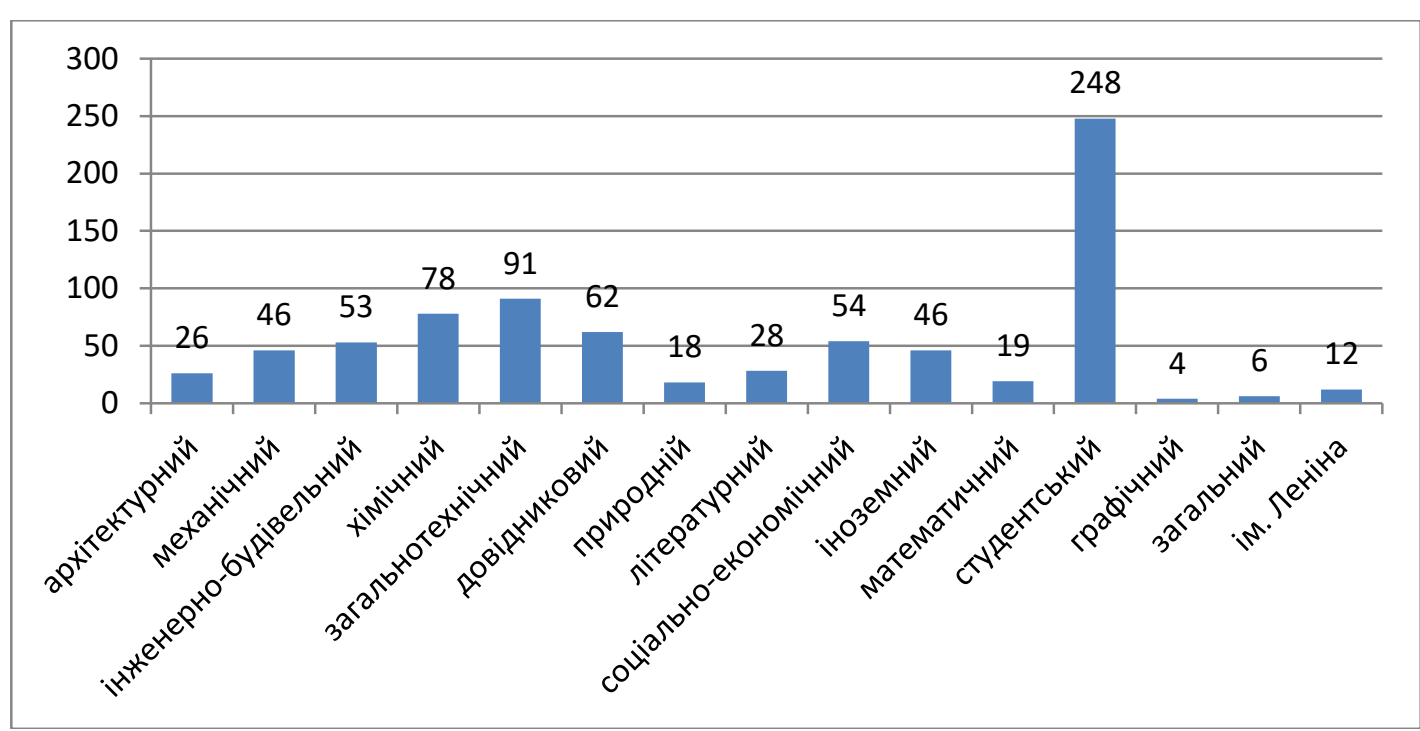

Рис. 1. Розподіл книг за відділами бібліотеки ВІТу станом на 1.01.1923 року

У зв’язку з важким матеріальним становищем закладів професійної освіти, 28 серпня 1922 року НКО УСРР було прийнято постанову про запровадження плати за навчання в усіх вищих навчальних закладах, окрім робітничо-селянських факультетів і вечірніх робітничих технікумів. Розміри такої плати залежали від вертикалей, соціального походження студентів тощо [14]. Плата за навчання у Волинському індустріальному технікумі була визначена на рівні 48 золотих карбованців в рік (пільговикам - 50 \% від цієї суми). Повну плату здійснювали 9 \% студентів технікуму, а 36 \% мали право на пільгову оплату. Теоретичний рівень надходжень від цієї статті доходів складав 2808 карбованців (912 крб - повна оплата, 1896 крб - пільгова оплата), але в розрахунку витрат використовувалась сума у 2106 крб (вважалось, що протягом року відбудеться зменшення кількості студентів на 25 \%) [15]. Відповідно до прибуткововидаткового кошторису, затвердженого Укрголовпрофосом, розподіл видатків від сплати за навчання представлено на рисунку 2.

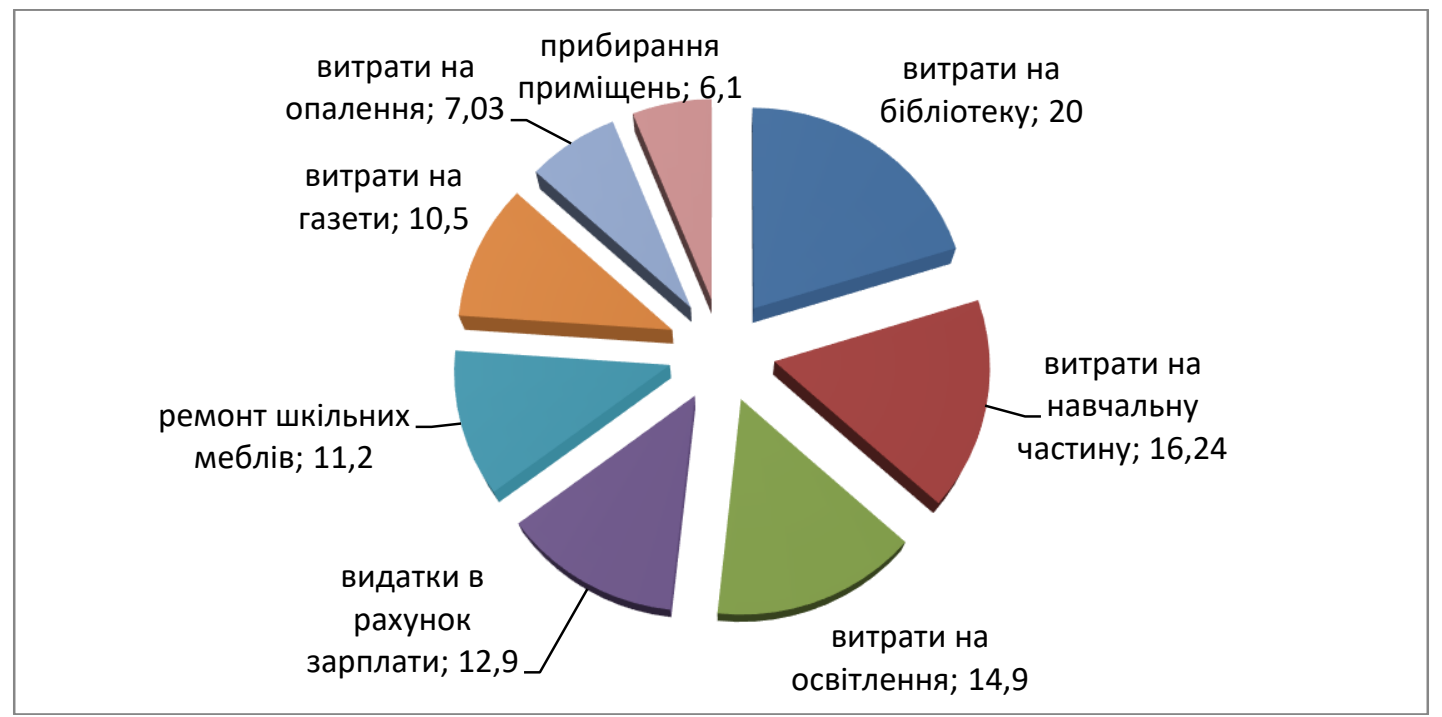

Рис. 2. Розподіл видатків від плати за навчання у 1922-1923 н. p., \% [16]

Для підтримки малозабезпечених студентів, згідно з постановою ВУЦВК «Про державні і приватні стипендії для учнів Вищих Шкільних Закладів і про Комітети допомоги учням ВУЗ» від 2 серпня 1922 року, почали виплачувати стипендії. Розмір державних стипендій залежав від поясного коефіцієнта, тобто від місця розташування навчального закладу, а студенти, які отримували такі стипендії, зобов'язувалися після закінчення навчального закладу відпрацювати на виробництві за спеціальністю по півтора року за кожний рік одержання стипендії [17]. 
31923 року в інститутах і технікумах обов'язковою стала виробнича практика, яка організовувалася під час літнього триместру й тривала 2-2,5 місяці. Після закінчення теоретичного навчання, за умови відсутності академзаборгованості, випускники вищих навчальних закладів проходили стажування (практику) на виробництві. Так починаючи з 1923 року, були прийняті законодавчі акти, які регулювали питання практики та стажування в Україні, а саме: Наказ № 458 від 1.10.1923 року «Об инструкции по проведению практического стажа окончивших ВУЗы»; Наказ № 25 від 24.01.1924 року «О порядке приема на стаж и практику»; Циркулярний лист № 5131 від 24.05.1924 року «О представлении в Комиссию по стажу при ВСНХ УССР полугодовых отчетов стажерами»; Циркулярний лист № 19845 від 2.09.1924 року «О приеме и оплате стажеров и практикантов» [18]. Ці постанови зобов'язували всі державні заклади, громадські організації та приватні підприємства надавати місця як для практики, так і для стажування студентам, які закінчили вищий навчальний заклад [19]. Завдяки угоді між Українською Радою Народного Господарства і Укрголовпрофосом студенти ВІТу в літні місяці 1923 року проходили практику на підприємствах об’єднань «Фарфор-Фаянс-Скло», «Бумтрест» (Київ), «Волинліс» [11].

Якщо мережа інженерно-технічних інститутів стабілізувалася вже у 1922 році після об'єднання в Катеринославі гірничого інституту та єврейського політехнікуму і злиття Київського народного політехнікуму з Київським політехнічним інститутом, то кількість денних технікумів, що у 1921 році сягала 64, скорочувалася у зв’язку з плановим вивченням Народним комісаріатом освіти їхньої життєдіяльності, і у 1925 році їх залишилося тільки 16 [20].

Зміну кількості установ інженерно-технічної освіти у 1921-1926 роках представлено у таблиці 3, а динаміку зміни кількості студентів - в таблиці 4.

Таблиия 3

Динаміка кількості закладів освіти

\begin{tabular}{|c|c|c|c|c|c|c|}
\hline \multirow{2}{*}{ Навчальні заклади } & \multicolumn{7}{|c|}{ Кількість закладів освіти за роками } \\
\cline { 2 - 7 } & 1921 & 1922 & 1923 & 1924 & 1925 & 1926 \\
\hline Інститути & 6 & 4 & 4 & 4 & 4 & 4 \\
\hline Технікуми денні & 64 & 51 & 28 & 19 & 16 & 16 \\
\hline Технікуми вечірні & 6 & 13 & 15 & 15 & 15 & 15 \\
\hline Технікуми транспортні & - & 17 & 19 & 12 & 11 & 13 \\
\hline
\end{tabular}

Таблиияя 4

Динаміка кількості студентів і учнів у закладах освіти

\begin{tabular}{|c|c|c|c|c|c|c|}
\hline \multirow{2}{*}{ Навчальні заклади } & \multicolumn{5}{|c|}{ Кількість студентів і учнів у закладах освіти за роками } \\
\cline { 2 - 7 } & 1921 & 1922 & 1923 & 1924 & 1925 & 1926 \\
\hline Інститути & 13964 & 8849 & 6989 & 6219 & 5395 & 5684 \\
\hline Технікуми денні & 11758 & 7983 & 4978 & 4363 & 3533 & 4306 \\
\hline Технікуми вечірні & 900 & 3224 & 2376 & 2297 & 1946 & 2604 \\
\hline Технікуми транспортні & - & 1896 & 3716 & 2987 & 1694 & 1600 \\
\hline
\end{tabular}

У квітні 1924 року було погоджено навчальні плани Волинського індустріального технікуму за спеціалізаціями: механічний факультет - теплотехніка, сільськогосподарські машини, гідромеханіка; будівельний факультет - шляхи, мости, комунальне будівництво; хімічний факультет - кераміка, силікатне виробництво, технологія органічних речовин [19]. Спробу відкрити спеціалізацію цукроваріння не підтримали в Головінспектурі інженерно-технічної освіти і не дозволили розвивати [21]. Це було обгрунтовано тим, що профспілка робітників цукрового виробництва разом із цукротрестом чітко встановили мережу шкіл і вищих навчальних закладів, комплектування учнів яких відбувалося лише за рахунок робітників підприємств певного регіону, а побудова нової лабораторій у ВІТі вимагала великих капіталовкладень [22]. Частина студентів 2-го курсу та викладачів продовжили наполягати на розвитку саме цукрової спеціалізації, незважаючи на відповідні рішення керівних органів освіти. Студенти фактично привласнили собі адміністративні функції і вимагали зміни викладачів та навчальних дисциплін [23]. Згідно з листом Волинського губернського відділу Наркомосвіти, 7 студентів другого курсу і 45 студентів першого курсу хотіли перевестися на навчання в Смілянський цукровий технікум, посилаючись на те, що вони навчалися за відповідною спеціалізацією. Студентам другого курсу такий дозвіл було надано, а от студентам першого - відмовлено [24]. Ситуація в Волинському індустріальному технікумі після цього не заспокоїлася, студенти продовжували скаржитись і вимагати змін, і тому у вересні 1924 року, для стабілізації ситуації у навчальному закладі, постановою Президії Укрголовпрофосвіти від 11/IX-24 року новим керівником технікуму було призначено Сергія Микитовича Левочкина [25]. 
Одже, на початку 20-х років XX сторіччя у Волинській губернії, відповідно до постанов уряду та Наркомосвіти УСРР, підготовку інженерів індустріально-технічного напряму за спеціальностями механічного, хімічного та будівельного напрямів здійснював єдиний заклад вищої освіти - Волинський індустріальний технікум. Те, що Волинський індустріальний технікум у першій половині 20-х років лишився серед провідних вишів України свідчить не лише про високий рівень підготовки фахівців, а і про надзусилля, які докладав колектив викладачів для становлення навчального закладу.

Здійснене дослідження не вичерпує всіх особливостей та проблем створення й становлення вищої індустріально-технічної освіти Волинської губернії. Перспективними напрямами для подальшого вивчення $є$ питання реформування української системи освіти і запровадження єдиної системи індустріально-технічної освіти в СРСР, а також вплив цих процесів на мережу навчальних закладів України.

Висновки. В першій половині 20-х років ХХ сторіччя в Україні було запроваджено систему підготовки інженерів у закладах освіти двох типів: технікумах й інститутах. Яскравим прикладом втілення цієї системи в життя стало становлення Волинського індустріального технікуму - єдиного індустріальнотехнічного закладу вищої освіти губернії. Головінспектура інженерно-технічної освіти, враховуючи особливу важливість закладу освіти для регіону, дозволила технікуму здійснювати підготовку значної кількості спеціальностей та спеціалізацій, хоча для закладів освіти цього рівня існувала вимога наявності лише одного факультету і підготовка працівників вищої кваліфікації окремої вузької галузі народного господарства та державного будівництва.

\section{Список використаної літератури:}

1. Свдокимов В.В. Становлення вищої технічної школи в Україні у 20-ті роки XX сторіччя / B.B. Свдокимов, O.B. Олійник, А.О. Чагайда // Економіка, управління та адміністрування. - 2019. - № 3 (89). - С. 3-7.

2. Отчет о состоянии Волынского индустриального техникума на 1 января 1922 года // ЦДАВО України. Ф. 166, оп. 2, спр. 1330, арк. 40.

3. Заключение Волгубпрофобра о состоянии и квалификации Волынского индустриального техникума. 13 мая 1922 г. // ЦДАВО України. - Ф. 166, оп. 2, спр. 1329, арк. 15.

4. Ряппо Я.П. Система народного образования на Украине / Я.П. Ряппо // Научный работник. - 1926. - № 7-8. C. 53-69.

5. В ИТО Укрглавпрофобра. 30 августа 1922 г. // ЦДАВО України. - Ф. 166, оп. 2, спр. 1329, арк. 34.

6. Волынскому губпрофобру. 13 сентября 1923 г. // ЦДАВО України. - Ф. 166, оп. 2, спр. 1328, арк. 34.

7. Сірополко С.О. Історія освіти в Україні / С.О. Сірополко. - К. : Наукова думка, 2001. - С. 746-748.

8. Сірополко С.О. Історія освіти в Україні / С.О. Сірополко. - К. : Наукова думка, 2001. - С. 738, 740.

9. Заключение ПТО Волгубсовнархоза о производственном значении Волынского индустриального техникума. 6 мая 1922 г. // ЦДАВО України. - Ф. 166, оп. 2, спр. 1329, арк. 7-8.

10. Доклад о подготовительных курсах при Волынском индустриальном техникуме имени Ленина // ЦДАВО України. - Ф. 166, оп. 2, спр. 1329, арк. 68-69.

11. Отчет Волынского индустриального техникума за 1922/23 уч. год // ЦДАВО України. - Ф. 166, оп. 2, спр. 1330, арк. 2-19.

12. Диаграмма роста технической библиотеки ВИТехникума // ЦДАВО України. - Ф. 166, оп. 2, спр. 1330, арк. 67.

13. Отчет Волынского индустриального техникума за 1922/23 уч. год // ЦДАВО України. - Ф. 166, оп. 2, спр. 1330, арк. 45-64.

14. Про платню за право навчання в шкільних установах Профосвіти // Бюлетень Наркомосвіти. - 1922. - Ч. 27 35. - C. 50.

15. Смета поступлений сумм в Волынский индустриальный техникум в течении 1922/23 уч. года // ЦДАВО України. - Ф. 166, оп. 2, спр. 1329, арк. 46.

16. Диаграмма распределения расходов, произведенных из сумм за правоучение студентов ВИТа в \% отношении - с начала учебного года по 15 мая 1923 г. // ЦДАВО України. - Ф. 166, оп. 2, спр. 1329, арк. 102.

17. Про державні і приватні стипендії для учнів Вищих Шкільних Закладів і про Комітети допомоги учням ВУЗ // Бюлетень Наркомосвіти. - 1922. - Ч. 27-35. - С. 5.

18. Матеріали про стан та організацію проходження студентами-випускниками технікумів України стажу i виробничої практики (протоколи, доповіді, доповідні записки, заяви, журнальні постанови, повідомлення, анкети, свідоцтва) // ЦДАВО України. - Ф. 166, оп. 5, спр. 598, арк. 23.

19. Ряппо Я. Производственная практика и стаж в системе профессионального образования / Я.Ряппо // Путь просвещения. - 1925. - № 5-6. - С. 6.

20. Звігальський Я. Професійна освіта на Україні / Я.Звігальський, М.Іванов. - Олександрія : Друк. місц. Комунгоспу, 1927. - С. 138.

21. Телеграмма Волынскому индустриальному техникуму // ЦДАВО України. - Ф.166, оп. 3, спр. 589, арк. 24.

22. Волынскому индустриальному техникуму. 18.04.1924 г. // ЦДАВО України. - Ф.166, оп. 3, спр. 589, арк. 19

23. ИТС Укрглавпрофобра. Не подлежит оглашению // ЦДАВО України. - Ф.166, оп. 4, спр. 428, арк. 5.

24. ИТО Укрглавпрофобра // ЦДАВО України. - Ф.166, оп. 4, спр. 428, арк. 4.

25. Посвідчення // ЦДАВО України. - Ф.166, оп. 3, спр. 589, арк. 36. 


\section{References:}

1. Ievdokymov, V.V., Olijnyk, O.V. and Chagajda, A.O. (2019), «Stanovlennja vyshhoi' tehnichnoi' shkoly v Ukrai'ni u 20-ti roky XX storichchja», Ekonomika, upravlinnja ta administruvannja, No. 3 (89), pp. 3-7.

2. CDAVO Ukrai'ny, Otchet o sostoyanii Volynskogo industrial'nogo tekhnikuma na 1 yanvarya 1922 goda, F. 166, op. 2, spr. 1330, ark. 40.

3. CDAVO Ukrai'ny, Zaklyuchenie Volgubprofobra o sostoyanii i kvalifikatsii Volynskogo industrial'nogo tekhnikuma. 13 maya 1922 g., F. 166, op. 2, spr. 1329, ark. 15.

4. Ryappo, Ya.P. (1926), «Sistema narodnogo obrazovaniya na Ukraine», Nauchnyi rabotnik, No. 7-8, pp. 53-69.

5. CDAVO Ukrai'ny, V ITO Ukrglavprofobra. 30 avgusta 1922 g., F. 166, op. 2, spr. 1329, ark. 34.

6. CDAVO Ukrai'ny, Volynskomu gubprofobru. 13 sentyabrya 1923 g., F. 166, op. 2, spr. 1328, ark. 34.

7. Siropolko, S.O. (2001), Istorija osvity v Ukrai'ni, Naukova dumka, K., pp. 746-748.

8. Siropolko, S.O. (2001), Istorija osvity v Ukrai'ni, Naukova dumka, K., P. 738, 740.

9. CDAVO Ukrai'ny, Zaklyuchenie PTO Volgubsovnarkhoza o proizvodstvennom znachenii Volynskogo industrial'nogo tekhnikum. 6 maya 1922 g., F. 166, op. 2, spr. 1329, ark. 7-8.

10. CDAVO Ukrai'ny, Doklad o podgotovitel'nykh kursakh pri Volynskom industrial'nom tekhnikume imeni Lenina, F. 166, op. 2, spr. 1329, ark. 68-69.

11. CDAVO Ukrai'ny, Otchet Volynskogo industrial'nogo tekhnikuma za 1922/23 uch. god, F. 166, op. 2, spr. 1330, ark. 2-19.

12. CDAVO Ukrai'ny, Diagramma rosta tekhnicheskoi biblioteki VITekhnikuma, F. 166, op. 2, spr. 1330, ark. 67.

13. CDAVO Ukrai'ny, Otchet Volynskogo industrial'nogo tekhnikuma za 1922/23 uch. god, F. 166, op. 2, spr. 1330, ark. 45-64.

14. «Pro platnju za pravo navchannja v shkil'nyh ustanovah Profosvity» (1922), Bjuleten' Narkomosvity, Part 27-35, P. 50.

15. CDAVO Ukrai'ny, Smeta postuplenii summ v Volynskii industrial'nyi tekhnikum v techenii 1922/23 uch. goda, F. 166, op. 2, spr. 1329, ark. 46.

16. CDAVO Ukrai'ny, Diagramma raspredeleniya raskhodov, proizvedennykh iz summ za pravouchenie studentov VITa $v \%$ otnoshenii - s nachala uchebnogo goda po 15 maya 1923 g., F. 166, op. 2, spr. 1329, ark. 102.

17. «Pro derzhavni i pryvatni stypendii' dlja uchniv Vyshhyh Shkil'nyh Zakladiv i pro Komitety dopomogy uchnjam VUZ» (1922), Bjuleten' Narkomosvity, Part 27-35, P. 5.

18. CDAVO Ukrai'ny, Materialy pro stan ta organizaciju prohodzhennja studentamy-vypusknykamy tehnikumiv Ukrai'ny stazhu i vyrobnychoi' praktyky (protokoly, dopovidi, dopovidni zapysky, zajavy, zhurnal'ni postanovy, povidomlennja, ankety, svidoctva), F. 166, op. 5, spr. 598, ark. 23.

19. Ryappo, Ya. (1925), «Proizvodstvennaya praktika i stazh v sisteme professional'nogo obrazovaniya», Put' prosveshcheniya, No. 5-6, S. 6.

20. Zvigal's'kyj, Ja. and Ivanov, M. (1927), Profesijna osvita na Ukrai'ni, Druk. misc. Komungospu, Oleksandrija, P. 138.

21. CDAVO Ukrai'ny, Telegramma Volynskomu industrial'nomu tekhnikumu, F.166, op. 3, spr. 589, ark. 24.

22. CDAVO Ukrai'ny, Volynskomu industrial'nomu tekhnikumu. 18.04.1924 g., F.166, op. 3, spr. 589, ark. 19.

23. CDAVO Ukrai'ny, ITS Ukrglavprofobra. Ne podlezhit oglasheniyu, F.166, op. 4, spr. 428, ark. 5.

24. CDAVO Ukrai'ny, ITO Ukrglavprofobra, F.166, op. 4, spr. 428, ark. 4

25. CDAVO Ukrai'ny, Posvidchennja, F.166, op. 3, spr. 589, ark. 36.

Свдокимов Віктор Валерійович - доктор економічних наук, професор, ректор Державного університету «Житомирська політехніка».

Наукові інтереси:

- проблеми національної економічної безпеки;

- розвиток вищої освіти в Україні.

Олійник Оксана Вікторівна - доктор економічних наук, професор, перший проректор Державного університету «Житомирська політехніка».

Наукові інтереси:

- обліково-аналітичне забезпечення системи управління;

- розвиток вищої освіти в Україні.

Чагайда Андрій Олегович - кандидат технічних наук, доцент кафедри менеджменту і туризму Державного університету «Житомирська політехніка».

Наукові інтереси:

- проблеми теорії та практики технології виробництва на підприємствах харчової промисловості;

- міні-технології на підприємствах готельно-ресторанного господарства;

- розвиток вищої освіти в Україні. 